\title{
ФЕДЕРАЛЬНАЯ ТАМОЖЕННАЯ СЛУЖБА КАК СУБЪЕКТ АДМИНИСТРАТИВНОЙ ЮРИСДИКЦИИ
}

\begin{abstract}
Аннотация. Статья посвящена правовой характеристике и особенностям административно-юрисдикиионной деятельности таможенных органов. Автор исследовал правовую основу и виды административно- юрисдикционных производств, порядок их процессуального оформления, а также их роль и значение в деятельности таможенных органов в условиях Таможенного союза в рамках ЕАЭС. Предметом статьи являются проблемы правового и организационного характера, связанные с административно-правовым регулированием производства по делам об административных правонарушениях. Автором подробно проводится теоретико-правовой анализ концепций административно-юрисдикционной деятельности. Основное внимание в статье уделяется разработки методов и методологии производства по делам об административных правонарушений в области таможенного дела. Методологическую основу статьи составили современные достижения теории познания. В процессе исследования применялись общефилософский, теоретический, общефилософские методы (диалектика, системный метод, анализ, синтез, аналогия, дедукция, наблюдение, моделирование), традиционно правовые методы (формально-логический), а также методы, используемые в конкретно-социологических исследованиях (статистические, экспертные оценки и др.). Основной вывод, который сделан по итогам исследования, состоит в том, что в настоящее время для обеспечения законности в области таможенного дела необходимо совершенствовать формы и методы процессуальной работы таможенных органов. Основным вкладом, который сделан автором в статье - это необходимость развития административно-правового регулирования производства по делам об административных правонарушениях. Новизна статьи заключается в разработке предложений по развитию форм и методов государственного регулирования таможенной деятельности, а также создание правовых и организационных гарантий законности в сорере таможенного администрирования.
\end{abstract}

Ключевые слова: таможня, принуждение, служба, субъект, ответственность, правонарушение, союз, кодекс, производство, закон.

Review. The article is devoted to legal description and features of administrative and jurisdictional activity of customs authorities. The author investigates the legal basis and the types of administrative - jurisdictional proceedings, the order of their registration and their role and importance in the activities of customs bodies in the Customs Union within the Eurasian Economic Union. The article focuses on the legal and organizational problems of administrative and legal regulation of administrative proceedings. The author carries out the theoretical and legal analysis of the concepts of administrative and jurisdictional activity. The main attention is paid to the development of methods and methodology of administrative proceedings in the customs sphere. The methodological base comprises the recent achievements of epistemology. The author applies the general philosophical and theoretical methods (dialectics, the systems approach, analysis, synthesis, analogy, deduction, observation and modeling), the traditional-legal methods (formal-logical), and special sociological methods (the statistical methods, expert assessments, etc.). The author concludes that at present in order to provide legality in the customs sphere it is necessary to improve the forms and methods of procedural activities of customs bodies. The author speaks about the necessity to develop administrative-legal regulation of administrative proceedings. The novelty of the research lies in the suggestions about the development of forms and methods of public regulation of customs activities and the provision of legal and organizational guarantees of legality in the sphere of customs administration.

Keywords: law, proceedings, code, Union, offence, liability, subject, service, coercion, custom.

$\mathrm{B}$ настоящее время в связи с созданием и функционированием Таможенного союза в рамках ЕАЭС роль Федеральной таможенной службы как органа исполнительной власти, уполномоченного в области таможенного дела, неуклонно возрастает. Таможенные органы в своей деятельности осуществляют ряд функций, в том числе и являются субъектом административной юрисдикции, для выполнения которых они обладают определенными правами. По мнению О.В. Чекалиной «в российском правоведении вопрос о сущности и содержании административной юрисдикции является одним из самых дискуссионных. Неоднозначный подход ученых к понимаю административной юрисдикции, влечет необходимость рассматривать данное правовое явление как системное образование» [1].

Наряду с этим, ученый А.В. Зубач отмечает: «исходя из предмета административно-правового регулирования, можно сделать вывод, что административная юрисдикция - это деятельность органов исполнительной власти и суда по разрешению 


\section{Административное и муниципальное право 10 (94) 2015}

административно-правового спора и по правовой оценке конкретных фактов вытекающих из управленческих правоотношений» [2].

По мнению автора, административная юрисдикция таможенных органов и их должностных лиц в современном законодательстве выражается в правовой оценке действий участников внешнеэкономической деятельности при перемещении товаров и транспортных средств через таможенную границу Таможенного союза, их помещения под различные таможенные процедуры, применение форм таможенного контроля, выполнения таможенных операций, а также уплаты налогов, пошлин и сборов; в назначении во внесудебном порядке на физических и юридических лиц, виновных в совершении правонарушений, предусмотренных КоАП РФ наказаний. При этом чаще всего указанная деятельность таможенных органов реализуется в административно-процессуальной форме производства по делам о нарушении таможенных правил, производства по жалобам и обращениям граждан на действия и решения должностных лиц, принимаемым в процессе таможенного, валютного, транспортного и иных видов контроля за соблюдением таможенного законодательства и ведения производства по данным делам, а также при привлечении должностных лиц таможенных органов к дисциплинарной ответственности за неправомерные решения, действия (бездействия).

Таким образом, основным содержанием административной юрисдикции таможенных органов в настоящее время является производство по делам об административных правонарушениях в области таможенного дела, производство по обращениям граждан и дисциплинарное производство.

Следует отметить, производство по обращениям граждан и дисциплинарное производство являются важными направлениями в административной юрисдикции таможенных органов, но доминирующее место по праву занимает производство по делам об административных правонарушениях.

Необходимо отметить, производство по обращениям граждан в таможенных органах - это регламентированная процессуальными нормами деятельность таможенных органов и их должностных лиц, направленная на рассмотрение и разрешение предложений, заявлений, жалоб и других обращений граждан.

Исходя из специфики данного производства, можно вести речь о четырех его стадиях, одна из которых является факультативной:

- возбуждение производства по обращению (подача обращения и его регистрация);

- рассмотрение обращения и принятие по нему решения;
- обжалование вынесенного решения (факультативная стадия);

- исполнение решения по обращению.

В современных условиях таможенные органы проводят работу с обращениями граждан руководствуясь в основном Федеральным законом от 02.05.2006 № 59-Ф3 «О порядке рассмотрения обращений граждан Российской Федерации» и Приказом ФТС от 30.06.2014 № 1240 «Об утверждении Порядка работы с обращениями граждан в ФТС России и таможенных органах Российской Федерации». Вопросы обжалования решений, действий (бездействий) таможенных органов и их должностных лиц в основном регулируются главой 3 ФЗ № - 311 «О таможенном регулировании в Российской Федерации».

Ежегодно в таможенные органы поступает значительное количество обращений и недоработки современного законодательства, и практика его применения в этой сфере вызывают необходимость дальнейшего совершенствования и оптимизации правовой базы и правоприменительной практики по данным вопросам.

Наряду с этим, дисциплинарное производство - это урегулированная правом деятельность уполномоченных субъектов, направленная на привлечение виновных к дисциплинарной ответственности.

Исходя из этого определения, под дисциплинарной ответственностью в таможенных органах понимают вид юридической ответственности, основным содержанием которой выступают меры, применяемые руководителями таможенных органов и учреждений, к должностным лицам таможенных органов и работникам, в связи с совершением им дисциплинарного проступка (дисциплинарное взыскание).

Виды дисциплинарных взысканий определены соответствующими нормативными актами:

- статья 192 ТК РФ дает общий перечень дисциплинарных взысканий, которые могут быть применены к работникам таможенных органов: замечание; выговор; увольнение;

- $\quad$ п. 1 ст. 57 Федерального закона «0 государственной гражданской службе Российской Федерации» за совершение дисциплинарного проступка гражданским служащим могут быть наложены следующие дисциплинарные взыскания: замечание; выговор; предупреждение о неполном должностном соответствии; освобождение от замещаемой должности гражданской службы; увольнение с гражданской службы по основаниям, установленным указанным Федеральным законом;

- ст. 29 Федерального закона «0 службе в таможенных органах Российской Федерации» уста- 
навливает следующие виды дисциплинарных взысканий, которые могут налагаться на сотрудников таможенных органов: замечание; выговор; строгий выговор; предупреждение о неполном служебном соответствии по результатам аттестации; увольнение из таможенных органов.

Необходимо констатировать, производство по наложению дисциплинарных взысканий на должностных лиц таможенных органов и работников, совершивших служебные проступки (не исполнивших или ненадлежащим образом исполнивших должностные обязанности), в настоящее время регламентировано различными нормативными правовыми актами, что предопределено наличием разных форм государственно-служебных и трудовых отношений (государственная гражданская служба, правоохранительная служба, работа в таможенных органах). Вместе с тем в определенных случаях на государственных служащих распространяются также нормы трудового законодательства и правила внутреннего трудового распорядка.

Основной нормативной базой по применению дисциплинарного производства в таможенных органах, являются:

- $\quad$ Федеральный закон от 27.07.2004 № 79-ФЗ «0 государственной гражданской службе Российской Федерации»;

- Трудовой кодекс Российской Федерации: Федеральный закон от 30 декабря 2001 г. № 197-Ф3;

- Федеральный закон от 21.07.1997 № 114-Ф3 «0 службе в таможенных органах Российской Федерации»;

- Указ Президента Российской Федерации от 16.11.1998 № 1396 «Об утверждении Дисциплинарного устава таможенной службы Российской Федерации»;

- Ведомственные нормативные акты.

В связи с этим можно определить следующие стадии дисциплинарного производства: принятие решения о возбуждении дисциплинарного производства, служебное расследование (проверка), принятие решения о дисциплинарном наказании, обжалование решения о дисциплинарном взыскании, исполнение наложенного взыскания.

Порядок наложения дисциплинарных взысканий на государственных гражданских служащих и сотрудников таможенных органов во многом схожи, но имеют и определенные отличия.

Например, в соответствии с п.2 ст. 58 Федерального закона «0 государственной гражданской службе Российской Федерации» перед применением дисциплинарного взыскания к государственному гражданскому служащему обязательно проводится служебная проверка, в ходе которой должны быть полностью, объективно и всесторонне уста- новлены: факт совершения дисциплинарного проступка; вина гражданского служащего; причины и условия, способствовавшие совершению дисциплинарного проступка; характер и размер вреда, причиненного гражданским служащим в результате дисциплинарного проступка; обстоятельства, послужившие основанием для письменного заявления гражданского служащего о проведении служебной проверки.

Наряду с этим, статья 19 Дисциплинарного устава таможенной службы РФ указывает, что до наложения дисциплинарного взыскания от сотрудника должно быть затребовано письменное объяснение. При необходимости проводится служебная проверка указанных в нем сведений с вынесением соответствующего заключения по ее результатам.

Однако 1 января 2016 года вступает в силу Федеральный закон № 262 - ФЗ от 13 июля 2015 года, нормы которого существенно изменят некоторые вопросы дисциплинарного производства в таможенных органах.

Резюмируя вышеизложенное, необходимо отметить, что для дисциплинарного производства специфической особенностью является то, что независимо от характера службы и работы, дисциплинарное взыскание налагается лицом (руководителем) таможенного органа или таможенного учреждения. Объясняется это тем, что дисциплинарное взыскание может быть наложено, как правило, в порядке служебного подчинения, т.е. руководителем, обладающим в отношении подчиненных работников дисциплинарной властью.

В области производства по делам об административных правонарушениях действующее административно - деликтное законодательство расширило диапазон правоприменительной деятельности таможенных органов. Наряду с административными правонарушениями в области таможенного дела Кодекс Российской Федерации об административных правонарушениях отнес к их ведению расследование и рассмотрение отдельных дел об административных правонарушениях охраны интелектуальной собственности, транспортного контроля, установленного порядка управления и т.д.

Как уже ранее отмечалось, административное производство занимает ведущее место в административно - юрисдикционной деятельности таможенных органов. Наряду с этим, следует отметить, вопросы административного производства являются актуальными для большинства правонарушений, совершаемых в Российской Федерации.

Например, «все последние годы прокуроры сталкиваются с предельно низким показателем исполнения судебных решений, начиная от уплаты штрафов за административное правонарушение и 


\section{Административное и муниципальное право 10 (94) • 2015}

заканчивая возмещением вреда от коррупционных проявлений. Итоги прошло (2014) года, из 5,5 трлн рублей, подлежащих принудительному взысканию, взыскано реально лишь 7,5\%. Причем последний год это положение стабильно ухудшается».

Следует отметить, что несмотря на либерализацию административного и таможенного законодательства количество дел, остается значительным и имеет тенденцию к росту. Как показывает анализ практики ФТС России за 2012 г. возбуждено 79170 дел, в 2013 г. - 79727 дел, в 2014 г. - 80385 дел. Закономерностью является возбуждение наибольшего количества дел по так называемым «контрабанднообразующим составам», правовое регулирование которых осуществляется статьями: 16.1, 16.2, 16.3 КоАП РФ, например в 2012 г. по ст. 16.2 «Недекларирование лили недостоверное декларирование товаров» возбуждено 21555 дел (27\% от общего количества), в 2013 г. - 22593 дел об (28\%), в 2014 г. - 23728 дел (30\%), а по ст. 16.3 «Несоблюдение запретов и (или) ограничений на ввоз товаров на таможенную территорию Таможенного союза или в Российскую Федерацию и (или) вывоз товаров с таможенной территории Таможенного союза или из Российской Федерации» в 2012 г. возбуждено 8960 дел (11\% от общего количества), в 2013 г. - 10602 дел (13\%), в 2014 г. - 9636 дел $(12 \%)$.

Масштабность административной деликтности в области таможенного дела, значительный ущерб экономическим интересам государства, причиняемый нарушениями таможенных правил, обусловливают необходимость адекватной реакции государства на эти противоправные проявления.

В целях противодействия указанным административным правонарушениям государство использует весь имеющийся у него арсенал политических, идеологических, экономических, организационных и правовых средств. Значительное место среди юридических средств занимают административные наказания как меры административной ответственности. Их применение оказывает не только превентивное воздействие на лиц, совершающих административные правонарушения, но и способствует предупреждению преступных деяний. Нормы КоАП РФ существенно расширили административно-юрисдикционную защиту общественных отношений в области таможенного дела. Таким образом, под административно-правовую охрану взяты как публичные отношения (таможенное дело, экономическая безопасность), так и интересы физических лиц, предпринимателей, юридических лиц, как участников внешнеэкономической деятельности.

Как уже отмечалось, Федеральная таможенная служба по кругу разрешаемых дел относится к ор- ганам исполнительной власти, наделенными административно - юрисдикционными полномочиями в области таможенного дела и выполняющим специальные функции.

В соответствии с нормами статьи 7 Таможенного кодекса Таможенного союза таможенные органы: - ведут административный процесс (осуществляют производство) по делам об административных правонарушениях и привлекают лиц к административной ответственности в соответствии с законодательством государств - членов таможенного союза.

Наряду с этим в Федеральном законе «0 таможенном регулировании в Российской Федерации»от 27 ноября 2010г. №311-Ф3 в ч.8 ст.12 определено, что таможенные органы:

- выявляют, предупреждают, пресекают административные правонарушения, отнесенные законодательством Российской Федерации к компетенции таможенных органов, осуществляют административное производство по делам об административных правонарушениях в области таможенного дела (о нарушениях таможенных правил).

В постановлении Правительства РФ от 16.09.2013 № 809 «О Федеральной таможенной службе» в части 5 п.44 подчеркивается, что таможенные органы осуществляют производство по делам об административных правонарушениях в области таможенного дела (о нарушениях таможенных правил) и иных административных правонарушениях, отнесенных законодательством Российской Федерации к компетенции таможенных органов.

В конкретном случае интерес вызывают юрисдикционные полномочия таможенных органов, осуществляемые уполномоченными должностными лицами в рамках правоохранительной функции, и юрисдикционный процесс как совокупность административно-процессуальных норм, регламентирующих деятельность таможенных органов по разрешению правовых споров и рассмотрению дел об административных правонарушениях и применению мер административного принуждения и ответственности.

В соответствии со статьей 23.8 КоАП РФ:

- таможенные органы рассматривают дела об административных правонарушениях, предусмотренных статьей 11.27 (в части осуществления международных автомобильных перевозок грузов), статьей 11.29 (в части осуществления международных автомобильных перевозок грузов), частями 1 - 3 статьи 12.21.1 (в части осуществления международных автомобильных перевозок), частью 1 статьи 12.21 .2 (в части осуществления международ- 
ных автомобильных перевозок опасных грузов без специального разрешения), частями 1 , 3 и 4 статьи 16.1, статьями 16.2 - 16.24 настоящего Кодекса.

- Рассматривать дела об административных правонарушениях от имени органов, указанных в части 1 настоящей статьи, вправе:

1) руководитель федерального органа исполнительной власти, уполномоченного в области таможенного дела, его заместители;

1.1) руководитель структурного подразделения федерального органа исполнительной власти, уполномоченного в области таможенного дела, его заместители;

2) начальники региональных таможенных управлений, их заместители;

3) начальники таможен, их заместители;

4) начальники таможенных постов, их заместители - об административных правонарушениях, совершенных физическими лицами;

5) иные должностные лица таможенных органов, уполномоченные на проведение таможенного контроля, осуществление других видов государственного контроля, выявление и пресечение административных правонарушений, осуществление производства по делам об административных правонарушениях, - об административных правонарушениях, предусмотренных частью 3 статьи 16.1, статьями $16.3,16.5,16.6,16.8,16.10,16.11$, частью 4 статьи 16.12 , статьями 16.13 - 16.15, частью 1 статьи 16.18, частью 3 статьи 16.19 настоящего Кодекса, совершенных физическими лицами, в случае, предусмотренном частью 1 статьи 28.6 КоАП России.

Резюмируя вышеизложенное, необходимо отметить, что, в соответствии с изменениями в законодательных актах, произошло расширение административно - юрисдикционных полномочий должностных лиц таможенных органов.

Однако полномочия вышеуказанных должностных лиц не одинаковы. Например, начальники таможенных постов могут рассматривать дела, только совершенные только физическими (должностными) лицами. Начальники РТУ, руководитель ФТС и его заместители могут рассматривать дела в первой и во второй инстанции (при обжаловании и пересмотре дел).

Особое место в осуществлении административно - юрисдикционной деятельности занимают должностные лица таможенных органов, уполномоченные на составление протокола об административном правонарушении, принятие мер обеспечения производства, ведение административного расследования. Действующее законодательство, в отличие от старых КоАП РСФСР и
Таможенного кодекса РФ, отграничило юрисдикционные полномочия этой категории должностных лиц, от полномочий лиц, рассматривающих дела об административных правонарушениях в области таможенного дела. Данные должностные лица стали самостоятельной процессуальной фигурой в административном производстве, вправе принимать по делам процессуальные решения, имеющие юридические последствия, принимать меры административного принуждения и нести ответственность за обоснованность и законность своих действий (п. 2, 3 ч. 1 ст. 22.2, п. 12 ч. 2 ст. 28.3 КоАП РФ). Наряду с этим, эти должностные лица вправе обжаловать постановления по делам об административным правонарушениям, принятые судьей (п.1 ст.30.1 КоАП РФ).

Таким образом, должностные лица таможенных органов вправе составлять протоколы при выявлении административных правонарушений, предусмотренных статьями (кроме ст.23.8) статьями $6.15,6.16,6.33$, частью 1 статьи 7.12, частью 4 статьи 8.28.1, статьями 11.14, 11.15, 14.10, 14.50, частью 1 статьи 15.6, частью 2 статьи 15.7, статьями 15.8, 15.9, частью 2 статьи 16.1, частью 1 статьи 19.4, частью 1 статьи 19.5, статьями 19.6, 19.7, частью 1 статьи 19.26, частью 2 статьи 20.23 (в ред. Федерального закона, от 31.12.2014 N 532-Ф3).

Должностные лица органов и агентов валютного контроля - об административных правонарушениях, предусмотренных статьей 15.25 , частью 1 статьи 19.4, частью 1 статьи 19.5, статьями 19.6, 19.7 настоящего Кодекса, а также в соответствии с п. 12 ч. 4 ст. 28.3 по части 1 статьи 20.25.

Перечень должностных лиц, уполномоченных составлять протоколы об административных правонарушениях определяется руководителем ФТС России и отдается приказом. В настоящее время действуют нормы приказа ФТС России от 02.12.2014 № 2344 «Об утверждении перечня должностных лиц таможенных органов Российской Федерации, уполномоченных составлять протоколы об административных правонарушениях и осуществлять административное задержание».

Доминирующая роль в нем отводится сотрудникам подразделений административных расследований и должностным лицам таможенных постов, а также некоторым должностным лицам таможенных органов.

Таким образом, в качестве выводов необходимо констатировать:

- в условиях действия Таможенного союза в рамках ЕАЭС административно - юрисдикционная деятельность является одним из важнейших направлений по выполнению функций и задач таможенными органами. Основными видами административно-юрисдикционной деятель- 
ности являются: производство по делам об административных правонарушениях в области таможенного дела, производство по обращениям граждан и дисциплинарное производство.

- однако, несмотря на либеризацию таможенного и административного законодательства, производство по делам об административных правонарушениях является главным и имеет тенденцию к росту.

- в связи с принятием Федерального закона № 262 - ФЗ от 13 июля 2015 года, который всту- пает в силу с 1 января 2016 года, нормы, регулирующие дисциплинарное производство в таможенных органах существенно изменятся. Наряду с этим для повышения эффективности и целесообразности усиления административной юрисдикции таможенных органов, устранения пробелов и коллизий в законодательстве необходимо дальнейшее совершенствование норм, регулирующих административно-юрисдикционную деятельность таможенных органов в условиях функционирования Таможенного союза ЕАЭС.

\section{Библиография:}

1. Чекалина О.В. Понятие административной юрисдикции //. Административное право и административный процесс: актуальные проблемы / отв. ред. Л.Л. Попов и М.С. Студеникина - М.: Юрист, 2004. С. 285.

2. Зубач А.В., Сафоненков П.Н., Сафоненкова О.А. Административная юрисдикционная деятельность таможенных органов: учебник для бакалавров / А.В. Зубач, П.Н. Сафоненков, О.А. Сафоненкова, М.: Издательство Юрайт, 2014. C 12

3. Зубач А.А. Правовое регулирование профессиональной этики таможенника в зарубежных странах // Полицейская деятельность. - 2013. - 1. - C. 44 - 53. DOI: 10.7256/2222-1964.2013.01.10.

4. Сидоров Е.И. Квалификации административных правонарушений, связанных с недекларированием либо недостоверным декларированием товаров в условиях функционирования Таможенного союза в рамках ЕАЭС // NB: Административное право и практика администрирования. - 2015. - 1. - С. 1 - 14. DOI: 10.7256/23069945.2015.1.15747. URL: http://www.e-notabene.ru/al/article_15747.html

5. Куракин А.В. Компетенция полиции в сфере реализации законодательства об административных правонарушениях // NB: Административное право и практика администрирования. - 2013. - 4. - С. 28 - 48. DOI: 10.7256/23069945.2013.4.8841. URL: http://www.e-notabene.ru/al/article_8841.html

6. Трунцевский Ю.В. Классификация мер уголовно-правового воздействия // Финансовое право и управление. 2015. - 2. - C. 137 - 144. DOI: 10.7256/2310-0508.2015.2.15682.

7. Житник Н.А., Ушакова И.В. Понятие и сущность производства по жалобам в деятельности таможенных органов // Полицейская деятельность. - 2013. - 2. - С. 107 - 110. DOI: 10.7256/2222-1964.2013.02.6.

\section{References (transliterated):}

1. Chekalina O.V. Ponyatie administrativnoi yurisdiktsii //. Administrativnoe pravo i administrativnyi protsess: aktual'nye problemy / otv. red. L.L. Popov i M.S. Studenikina - M.: Yurist, 2004. S. 285.

2. Zubach A.V., Safonenkov P.N., Safonenkova O.A. Administrativnaya yurisdiktsionnaya deyatel'nost' tamozhennykh organov: uchebnik dlya bakalavrov / A.V. Zubach, P.N. Safonenkov, O.A. Safonenkova, M.: Izdatel'stvo Yurait, 2014 . S 12

3. Zubach A.A. Pravovoe regulirovanie professional'noi etiki tamozhennika v zarubezhnykh stranakh // Politseiskaya deyatel'nost'. - 2013. - 1. - C. 44 - 53. DOI: 10.7256/2222-1964.2013.01.10.

4. Sidorov E.I. Kvalifikatsii administrativnykh pravonarushenii, svyazannykh s nedeklarirovaniem libo nedostovernym deklarirovaniem tovarov v usloviyakh funktsionirovaniya Tamozhennogo soyuza v ramkakh EAES // NB: Administrativnoe pravo i praktika administrirovaniya. - 2015. - 1. - C. 1 - 14. DOI: 10.7256/2306-9945.2015.1.15747. URL: http://www.enotabene.ru/al/article_15747.html

5. Kurakin A.V. Kompetentsiya politsii v sfere realizatsii zakonodatel'stva ob administrativnykh pravonarusheniyakh // NB: Administrativnoe pravo i praktika administrirovaniya. - 2013. - 4. - C. 28 - 48. DOI: 10.7256/2306-9945.2013.4.8841. URL: http://www.e-notabene.ru/al/article_8841.html

6. Truntsevskii Yu.V. Klassifikatsiya mer ugolovno-pravovogo vozdeistviya // Finansovoe pravo i upravlenie. - 2015. - 2. - C. 137 - 144. DOI: 10.7256/2310-0508.2015.2.15682.

7. Zhitnik N.A., Ushakova I.V. Ponyatie i sushchnost' proizvodstva po zhalobam v deyatel'nosti tamozhennykh organov // Politseiskaya deyatel'nost'. - 2013. - 2. - C. 107 - 110. DOI: 10.7256/2222-1964.2013.02.6. 